\title{
Benzethonium Chloride Catalyzed One Pot Synthesis of 2,4,5-trisubstituted Imidazoles and 1,2,4,5-tetrasubstituted Imidazoles in Aqueous Ethanol as a Green Solvent
}

\author{
D. PARTHIBAN ${ }^{1}$ and R. JOEL KARUNAKARAN²* \\ 'Department of Chemistry, Arignar Anna Govt Arts College, Cheyyar, India-604407. \\ ${ }^{2}$ Department of Chemistry, Madras Christian College, Tambaram, Chennai, India-600059. \\ ${ }^{*}$ Corresponding author E-mail: rjkmcc@ yahoo.com \\ http://dx.doi.org/10.13005/ojc/340642
}

Received: August 23, 2018; Accepted: November 04, 2018)

\begin{abstract}
A simple, efficient procedure has been developed using $\mathrm{N}$-cationic surfactant namely Benzethonium chloride (BzthCl, $10 \mathrm{~mol} \%$ ) as novel catalyst for the synthesis of 2,4,5-trisubstituted imidazoles by condensation of aldehyde, ammonium acetate and benzil using $\mathrm{EtOH}-\mathrm{H}_{2} \mathrm{O}(1: 1)$ as a green solvent at $70^{\circ} \mathrm{C}$. Same reaction condition was applied successfully to demonstrate the synthesis of various 1,2,4,5-tetrasubstitued imidazoles using aromatic amine as fourth component. The use of benzethonium chloride as a catalyst with dual functionality as surfactant and ionic liquid catalyst is the main novelty of described method. The significant feature of this greener protocol includes high product yields, procedural simplicity and lesser reaction time.
\end{abstract}

Keywords: 2,4,5-trisubstituted imidazoles, Multicomponent reaction, Benzethonium chloride, $\mathrm{N}$-cationic surfactant.

\section{INTRODUCTION}

Multi-component reactions (MCRs) play a significant role in modern organic synthesis because they are one-pot organic transformations that assemble three or more substrates into single desired product. MCRs have been receiving overwhelming response from scientific research communities for well over time owing to their synthetic efficiency of organic transformation, atom economy, environmentally benign process, lower energy consumption, minimal by-product formation and procedural simplicity. Moreover they serve as versatile tools for construction of biologically and pharmaceutically active heterocyclic motifs. ${ }^{1,2}$ The imidazole derivatives exhibit a broad spectrum of biological and pharmacological activities such as antifungal, ${ }^{3}$ analgesic and anti-inflammatory, ${ }^{4}$ bactericidal, ${ }^{5}$ antitumor, ${ }^{6}$ herbicidal, ${ }^{7}$ anticancer, ${ }^{8}$ These compounds also show inhibition against few enzymes such as heme oxygenase-1, HMG-CoA reductase, fatty acid amide hydrolase. ${ }^{9}$ Cimetidine $^{10}$-a histamine $\mathrm{H}_{2}$ receptor antagonist that inhibits stomach acid production, Omeprazole ${ }^{11}$-a proton pump inhibitor used for treatment of gastrophageous reflux disease,

This is an Open Access article licensed under a Creative Commons license: Attribution 4.0 International (CC- BY). Published by Oriental Scientific Publishing Company @ 2018

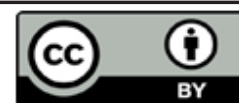


Trifenagre $^{12}$-a potent arachidonate cyclooxygenase inhibitor, Eprosartan ${ }^{13}$-an angiotensin II receptor antagonist, are few to exemplify the pharmacologically active synthetic imidazoles. (Fig.1) Imidazole derivatives are used as task specific ionic liquids (TSIL), which in turn used as catalyst, green solvents since TSIL possess low vapour pressure and temperature stability. ${ }^{14}$ The photosensitive imidazole compounds are used in photography. ${ }^{15}$<smiles>CN=C(NC)NCCSCc1nc[nH]c1C</smiles>

Cimetidine

(an anti-ulcerative agent)<smiles>CN(C)CCOc1ccccc1-c1nc(-c2ccccc2)c(-c2ccccc2)[nH]1</smiles>

Trifenagrel

(an arachidonate COX inhibitor)<smiles>COc1ccc2[nH]c(S(=O)Cc3ncc(C)c(OC)c3C)nc2c1</smiles>

Omeprazole (a proton pump inhibitor)<smiles>CCCCc1ncc(C=C(Cc2cccs2)C(=O)O)n1Cc1ccc(C(=O)O)cc1</smiles>

Eprosartan (a vasodiltor agent)

Fig. 1. Biologically active imidazole compounds

Owing to the wide applicability of imidazole derivatives in the laboratories, industries and pharmaceutical ventures, many methods have been developed for the synthesis of 2,4,5-trisubstituted imidazoles and 1,2,4,5-tetrasubstituted imidazoles by employing various catalyst like $\mathrm{SiO}_{2}: \mathrm{SnO}_{2}$ nanoparticles, ${ }^{16}$ Silica chloride $\left(\mathrm{SiO}_{2}-\mathrm{Cl}\right),{ }^{17}, \mathrm{SBA}-\mathrm{Pr}-$ $\mathrm{SO}_{3} \mathrm{H},{ }^{18} \mathrm{~N}$-acetyl glycine (NAG), ${ }^{19}\left[{ }^{2} \mathrm{bmim}\right]_{3}\left[\mathrm{GdCl}_{6}\right],{ }^{20}$ $\mathrm{Fe}_{2} \mathrm{O}_{3} / \mathrm{ChCl}$-Urea eutectic mixture, ${ }^{21} 10$-molybdo2-vanadophosphoric acid/ KSF montmorillonite, ${ }^{22}$ $\mathrm{PivOH} / \mathrm{NH}_{4} \mathrm{OAc}^{23}, \mathrm{CuFe}_{2} \mathrm{O}_{4}$ Magnetic nanoparticles, ${ }^{24}$ $\mathrm{H}_{3} \mathrm{PW}_{12} \mathrm{O}_{40} \cdot 23 \mathrm{H}_{2} \mathrm{O} / \mathrm{PS} @ \mathrm{Si}^{25}$ [Dsim] $\mathrm{HSO}_{4},{ }^{26}$ silica-supported $\mathrm{SbCl}_{3} .{ }^{27}$ However, most of the methods employed for triaryl imidzoles synthesis have drawbacks such as the use of strongly acidic conditions, the use of protic acids, prolonged reaction times, high temperature, high catalyst loading, low-to-moderate yields, volatile organic solvents and toxic transition metal catalyst.

An important drawback of conventional synthesis of trisubstituted imidazoles is that expensive polar aprotic solvents are used in order to solubilise organic substrates together with inorganic compounds, thereby, high temperatures are used to make them soluble and to get high yield of the product; consequently, the salts accumulated in the mixture slow down the reaction rate by poisoning the catalyst. But this problem can be overcome by using surfactant system for catalytic organic transformations. Surfactant system has received considerable interest as eco-friendly catalysts and reagents in organic transformations, because surfactant systems are characterized by their high capacity for reactants solubilisation, which enables them as medium and catalyst for organic, inorganic, polar, and non-polar reactant. They also possess large liquid-liquid interfacial area which allows faster diffusion between phases. ${ }^{28}$ electrostatic and hydrophobic interactions of surfactants with reactants has great influence on reactions progress. ${ }^{29}$

The use of quaternary ammonium salts such as tributylhexadecylphosphonium bromide,,$^{30}$ tetrabutylammonium bromide ${ }^{31}$ as a catalyst for synthesis of tri-, tetra- substituted imidazoles has been reported recently in the literature. Surfactant property of various quaternary ammonium salts by micellar formation has been well documented in the literature. ${ }^{32,33,34,35}$. Benzethonium chloride (BzthCl) is a synthetic quaternary ammonium salt belongs to the class of bi-tailed $\mathrm{N}$-cationic surfactants, and it is chemically known as N-benzyl-N,N-dimethyl-2(2-(4-(2,4,4-trimethylpentan-2-yl)phenoxy)ethoxy) ethanaminium chloride. (Fig. 2) This compound has surfactant and anti-infective properties..$^{36}$ It is used in topical antiseptic, mouthwashes, deodorants, anti-itching ointments, cosmetics. To the best of our knowledge, benzethonium chloride has not been used earlier as a catalyst in organic synthesis.

From both economical and green chemistry point of view, design of synthetic organic transformations should be done using substances that exhibit little or no toxicity to the environment and human health. EtOH- $\mathrm{H}_{2} \mathrm{O}(1: 1)$ has emerging as a promising solvent system for organic synthesis, because it is inexpensive, stable, less volatile and non-toxic. ${ }^{37}$ Moreover, Capello and co-workers ${ }^{38}$ reported that ethanol-water mixtures are ecologically safe compared to pure alcohol for organic synthesis.<smiles>CC(C)(C)CC(C)(C)c1ccc(OCCOCC[N+](C)(Cl)Cc2ccccc2)cc1</smiles>

Fig. 2. Structure of benzethonium chloride

In continuation of our search for simple nonhazardous methods for organic transformation $39,40,41,42$, especially for the synthesis of biologically important heterocyclic organic compounds via multicomponent 
reaction, ${ }^{43}$ herein we wish to report a facile, efficient, and environmentally friendly procedure for the synthesis of 2,4,5-trisubstituted imidazoles via one-pot multi-component reaction of benzil, aromatic aldehyde, and ammonium acetate in excellent yields using benzethonium chloride as a catalyst in $\mathrm{EtOH}-$ $\mathrm{H}_{2} \mathrm{O}(1: 1)$ mixture (Scheme 1).

\section{EXPERIMENTAL}

Various aromatic aldehyde, benzil, ammonium acetate and other chemicals were purchased from SD fine, and Avra chemicals. They were used without further purification. Silica gel (Column grade) was purchased from SD fine chemicals. The solvents were purified as per the standard procedure reported in literature. Melting points were measured in open capillary tubes on DeepVision melting point apparatus and are reported uncorrected. Thin layer chromatography was carried out on pre-coated sheets of silica gel containing 60 F254 indicator (Merck, Darmstadt, Germany). Column chromatography was performed with silica gel (60-120 mesh; SD Fine). ${ }^{1} \mathrm{H}-\mathrm{NMR}$ spectra were recorded on $500 \mathrm{MHz}$ Brucker Advance instrument in DMSO- $d_{6}$ solvent. ${ }^{13} \mathrm{C}-\mathrm{NMR}$ spectra were recorded on $100 \mathrm{MHz}$ Brucker Advance instrument in DMSO-d solvent, chemical shifts $(\delta)$ are expressed in ppm value relative to the internal standard TMS. FT-IR of all the samples was recorded on Brucker alpha-P spectrophotometer. Mass spectra were recorded on Jeol GC Mate II mass spectrometer.

\section{General procedure for the synthesis of $2,4,5-$ trisubstituted imidazoles (Scheme 1)}

The mixture of aromatic aldehyde (10 mmol), benzil (10 mmol), ammonium acetate (20 mmol), benzethonium chloride (10 mole \%) and $10 \mathrm{ml}$ of $\mathrm{EtOH}: \mathrm{H}_{2} \mathrm{O}(1: 1)$ solvent mixture was taken in $100 \mathrm{ml}$ round bottom flask, heated and maintained at $70^{\circ} \mathrm{C}$ with stirring for appropriate time and the progress of the reaction was monitored by TLC. After completion of the reaction as indicated by TLC, the reaction mixture was cooled to room temperature. The reaction mixture was diluted with $10.0 \mathrm{~mL}$ of water. The product was extracted with $2 \times 10 \mathrm{~mL}$ of ethyl acetate. The organic layer was dried by $\mathrm{MgSO}_{4}$ The organic layer was concentrated under vacuum, and the product was purified either by recrystallizing in hot ethanol or by column chromatography on silica gel (60-120 Mesh, 20\% EtOAc/Petroleum ether mixture). All the products were thoroughly characterized by FT-IR, ${ }^{1} \mathrm{H}-\mathrm{NMR},{ }^{13} \mathrm{C}-\mathrm{NMR}$, Mass spectral analysis.

\section{General procedure for the synthesis of $1,2,4,5-$} tetrasubstituted imidazoles (Scheme 2)

The mixture of aromatic aldehyde (10 $\mathrm{mmol})$, aromatic primary amine $(10 \mathrm{mmol})$, benzil $(10 \mathrm{mmol})$, ammonium acetate $(10 \mathrm{mmol})$, benzethonium chloride (10 mole \%) and $10 \mathrm{ml}$ of EtOH: $\mathrm{H}_{2} \mathrm{O}(1: 1)$ solvent mixture was taken in $100 \mathrm{ml}$ round bottom flask, heated and maintained at $70^{\circ} \mathrm{C}$ with stirring for appropriate time and the progress of the reaction was monitored by TLC. After completion of the reaction as indicated by TLC, the reaction mixture was cooled to room temperature. The reaction volume was reduced and diluted with $10.0 \mathrm{~mL}$ of water. The product was extracted with $2 \times 10 \mathrm{~mL}$ of ethyl acetate. The organic layer was dried by $\mathrm{MgSO}_{4}$. The organic layer was concentrated under vacuum, and the product was purified either by recrystallizing in hot ethanol or by column chromatography on silica gel (60-120 Mesh, 20\% EtOAc/Petroleum ether mixture). All the products were thoroughly characterized by FT-IR, ${ }^{1} \mathrm{H}-\mathrm{NMR}$, ${ }^{13} \mathrm{C}-\mathrm{NMR}$, Mass spectral analysis.

\section{RESULTS AND DISCUSSION}

Initially, we investigated the threecomponent condensation reaction of benzil (10 mmol), benzaldehyde (10 mmol), and ammonium acetate $(20 \mathrm{mmol})$ in $10 \mathrm{~mL}$ of $\mathrm{EtOH}$ in the absence of benzethonium chloride at room temperature for about 8 hours. Only trace amount of the corresponding product was obtained (Table 1, entry 1). Then, we carried out the reaction under similar conditions in the presence of $10 \mathrm{~mol} \%$ of benzethonium chloride. Surprisingly, the product was obtained in $21 \%$ yield. This observation clearly indicates that, if the reaction conditions such solvent, reaction time, temperature and catalyst load are properly optimized, benzethonium chloride can be used as an effective catalyst for this condensation reaction.

The reaction temperature is considered as important parameter for determining the feasibility of chemical reactions, the reaction temperature 
is particularly important with respect to one pot MCR reaction because very high temperatures frequently lead to formation of numerous unwanted side products. So, in order to study the influence of temperature on product yield, we have performed<smiles>O=C(C(=O)c1ccccc1)c1ccccc1</smiles><smiles>[X]c1ccc(C=O)cc1</smiles>
$+\mathrm{NH}_{4}{ }^{+} \mathrm{OAc}-\frac{\text { Benzethonium chloride }}{\text { EtOH: } \mathrm{H}_{2} \mathrm{O}(1: 1), 70{ }^{0} \mathrm{C}}$ $\mathrm{X}=\mathrm{H}, 4-\mathrm{Br}, 4-\mathrm{Cl}, 2-\mathrm{OH}, 4-\mathrm{OH}, 4-\mathrm{CH}_{3}, 4-\mathrm{OCH}_{3}$ cyclocondensation reaction by varying the temperature from $40^{\circ} \mathrm{C}$ to $100^{\circ} \mathrm{C}$ by increment of $10^{\circ} \mathrm{C}$, highest yield of $83 \%$ was obtained at $70^{\circ} \mathrm{C}$, and the temperature beyond $70^{\circ} \mathrm{C}$, there was no significant change in product yield (Table 1).

$$
\text { Scheme 1. Benzethonium chloride catalyzed synthesis of 2,4,5-trisubstituted imidazoles }
$$

Table 1: Effect of temperature on synthesis of trisubstituted imidazole

\begin{tabular}{cccc}
\hline Entry & Temp $\left({ }^{\circ} \mathrm{C}\right)$ & Time $(\mathrm{h})$ & Yield $(\%)$ \\
\hline 1 & r.t & 8 & 21 \\
2 & 40 & 8 & 32 \\
3 & 50 & 8 & 38 \\
4 & 60 & 6 & 51 \\
5 & 70 & 1.5 & 83 \\
6 & 80 & 1.5 & 83 \\
7 & 90 & 1.5 & 82 \\
8 & 100 & 1.5 & 81 \\
\hline
\end{tabular}

To study the effect of solvent, the reaction was carried out at $70^{\circ} \mathrm{C}$ using benzethonium chloride as catalyst in different solvent such as acetone ethanol, methanol and acetonitrile etc. we found that, in non-polar solvents such as dichloromethane, acetone, and acetonitrile, the products were obtained in poor yield (Table 2, entry 2, 5, 6). However, in polar solvents like ethanol, methanol the product was obtained in moderate yield in comparison with nonpolar solvents (Table 2, entry 3, 4). When the reaction was performed in water, $39 \%$ product was formed. Then, we found that ethanol-water (1:1) mixture seemed to be most appropriate reaction medium, and gives $95 \%$ of product yield. (Table 2 ; entry 7 ).

To demonstrate the effect of surfactant/ quaternary ammonium salt as catalyst, various commercially available cationic, anionic and non-ionic surfactants were employed for the cyclocondensation reaction of benzaldehyde, benzil, and ammonium acetate in ethanol-water $(1: 1, \mathrm{v} / \mathrm{v})$ system and the obtained results are summarized in Table 3. It is observed that for all other quaternary ammonium salt/surfactant used as catalysts, very low conversion of 2,4,5-trisubstituted imidazoles was achieved. It was found that the catalytic ability of benzethonium chloride was superior to other quaternary ammonium salt. Thus, the best result was obtained for benzethonium chloride. (Table 3, entry 4). This observation is due to the fact that benzethonium chloride contains two strong hydrophobic tails (R'=1-(2-ethoxyethoxy)-4-(2,4,4-trimethylpentan-2yl)phenyl, R"= benzyl), (Fig. 1), the hydrophobicity inside the miceller core of benzethonium chloride is higher when compared to other quaternary ammonium salt such as benzyltriethylammonium chloride (TEBAC), benzyltripropylammonium chloride (TPBAC), benzyltributylammonium chloride (TBAC) etc., and consequently it gives higher product yield.( entry 4 of Table 3).

Table 2: Effect of solvent on synthesis of trisubstituted imidazoles"

\begin{tabular}{cccc}
\hline Entry & Solvent & Temp $\left({ }^{\circ} \mathrm{C}\right)$ & Yield (\%) \\
\hline 1 & Water & 70 & 39 \\
2 & Acetone & 70 & 33 \\
3 & Methanol & 70 & 53 \\
4 & Ethanol & 70 & 82 \\
5 & Dichloromethane & 70 & 29 \\
6 & Acetonitrile & 70 & 27 \\
7 & Ethanol-water(1:1)a & 70 & 95 \\
8 & Ethanol-water(1:3) & 70 & 71 \\
9 & Ethanol-water(3:1) & 70 & 82 \\
10 & Ethanol-water(1:1)b & 70 & 94 \\
11 & Ethanol-water(1:1)c & 70 & 93 \\
\hline
\end{tabular}

\#The reaction was conducted with benzil $(10 \mathrm{mmol})$, benzaldehyde $(10 \mathrm{mmol})$ and ammonium acetate (20 mmol) using $10 \mathrm{~mol} \%$ of benzethonium chloride catalyst at $70^{\circ} \mathrm{C}$.

a catalytst $(10 \mathrm{~mol} \%)$

b catalytst $(15 \mathrm{~mol} \%)$

c catalytst $(20 \mathrm{~mol} \%)$ 
Table 3: Effect of catalyst on synthesis of trisubstituted imidazoles"\#

\begin{tabular}{clcc}
\hline Entry & Surfactant/Quaternary ammonium salt & Temp $\left({ }^{\circ} \mathrm{C}\right)$ & Yield (\%) \\
\hline 1 & Benzyltriethylammonium chloride(TEBAC) & 70 & 13 \\
2 & Benzyltripropylammonium chloride(TPBAC) & 70 & 21 \\
3 & Benzyltributylammonium chloride (TBAC) & 70 & 45 \\
4 & Benzethonium chloride (BzthCl) & 70 & 95 \\
5 & sodiumdodecyl sulfate (SDS) & 70 & 29 \\
6 & Cetyltrimethylammonium bromide(TMCAB) & 70 & 31 \\
7 & Triton X-100 & 70 & 37 \\
\hline
\end{tabular}

\#\#The reaction was conducted with benzil $(10 \mathrm{mmol})$, benzaldehyde $(10 \mathrm{mmol})$ and ammonium acetate $(20 \mathrm{mmol})$ using different catalyst at $70^{\circ} \mathrm{C}$

Table 4: Benzethonium chloride catalyzed synthesis of 2,4,5-trisubstituted imidazoles

\begin{tabular}{|c|c|c|c|c|c|c|}
\hline \multirow[t]{2}{*}{ Entry } & \multirow[t]{2}{*}{ Aldehyde } & \multirow[t]{2}{*}{ Product } & \multirow[t]{2}{*}{ Time(min.) } & \multirow[t]{2}{*}{ Yield(\%) } & \multicolumn{2}{|c|}{ Melting point $\left({ }^{\circ} \mathrm{C}\right)$} \\
\hline & & & & & Found & Lit \\
\hline a & & & 45 & 95 & 273-275 & $270-272^{17}$ \\
\hline$b$ & & & 60 & 89 & 300-302 & $302-304^{22}$ \\
\hline c & & & 45 & 85 & $248-250$ & $250-252^{22}$ \\
\hline d & & & 45 & 94 & $263-265$ & $260-265^{17}$ \\
\hline e & & & 60 & 81 & $200-201$ & $200-202^{17}$ \\
\hline$f$ & & & 60 & 87 & $238-240$ & $235-237^{17}$ \\
\hline g & & & 60 & 89 & $229-231$ & $232-234^{22}$ \\
\hline $\mathrm{h}$ & & & 60 & 90 & $219-221$ & $220-223^{25}$ \\
\hline i & & & 45 & 91 & $231-233$ & $230-232^{17}$ \\
\hline j & & & 90 & 79 & 233-234 & $230-232^{22}$ \\
\hline $\mathrm{k}$ & & & 75 & 83 & 200-202 & $202-204^{22}$ \\
\hline I & & & 60 & 86 & $257-259$ & $255-257^{22}$ \\
\hline
\end{tabular}


In order to study the practical applicability of this condensation reaction, a series of 2,4,5trisubstituted imidazoles were synthesized from benzil, ammonium acetate with various aldehydes, in the presence of $10 \mathrm{~mol} \%$ benzethonium chloride in EtOH-water(1:1) mixture at reflux temperature (Table 4). An array of aromatic aldehyde was found to be suitable reactant to form the corresponding trisubstituted imidazoles in high yields. Aromatic aldehydes having electron-donating and withdrawing groups were well tolerated (Table 4, entries a-e). Interestingly, heterocyclic aldehyde such as furaldehyde, thiophene carboxaldehyde were also very good candidates

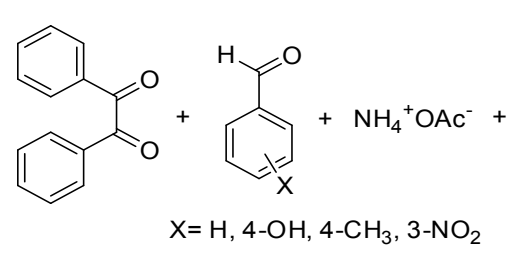

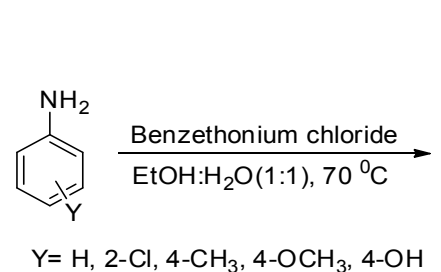

for the reaction, providing highly substituted imidazoles in excellent yields (Table 4, entry j,k,l.) Alkyl aldehyde, such as isobutyraldehyde was also underwent reaction smoothly with $91 \%$ product yield. (Table 4, entry i).

Encouraged by the success of a three component reaction, the attention was turned to evaluate feasibility of our protocol for the synthesis of tetrasubstituted imidazole derivatives by utilizing four component reactions under identical reaction conditions with the addition of a stoichiometric ratio of various aromatic amines as the fourth component (Scheme 2).

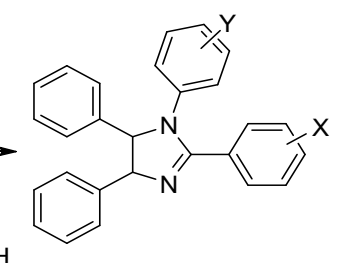

Scheme 2. Benzethonium chloride catalyzed Synthesis of 1,2,4,5-trisubstituted imidazoles

To our surprise, the reaction underwent smoothly irrespective of nature, electronic effect of the substituent on the aromatic rings, and obtained the desired tetrasubstituted imidazole compounds in excellent yields. (Table 5, entry a-h). From these results, it is clear that aniline with electron donating alkyl and alkoxy group such as toluene, anisidine (Table 5, entry e, g, h) reacted smoothly and resulted in high yield. When aniline with electron withdrawing group such as chloroaniline, nitroaniline were used they reaction rate is decreased slightly.

All the synthesized compounds were characterized by FT-IR, ${ }^{1} \mathrm{H}$ NMR, ${ }^{13} \mathrm{C}$ NMR, and Mass spectral analysis. IR spectra of the compounds show characteristic absorption band at $3207-3261 \mathrm{~cm}^{-1}$ for $\mathrm{N}-\mathrm{H}$ stretch, $3010-3072 \mathrm{~cm}^{-1}$ for aromatic $\mathrm{C}-\mathrm{H}$ group, $1628-1678 \mathrm{~cm}^{-1}$ for $\mathrm{C}=\mathrm{N}$ group, around 1580 for $\mathrm{C}=\mathrm{C}$ groups. The ${ }^{1} \mathrm{H}$ NMR spectrum of all compounds shows characteristic peaks at 7.10-8.97 ppm for aromatic protons of all the 2,4,5-trisubstituted imidazoles and 1,2,4,5-tetrasubstituted imidazoles. The $\mathrm{N}-\mathrm{H}$ proton appeared as a singl et al., 12.50 ppm in all the spectra. The other signals and peaks of the IR and ${ }^{1} \mathrm{H}$ NMR are in complete agreement with the assigned structures. ${ }^{13} \mathrm{C}$ NMR exhibited peaks characteristic for the compounds. The mass spectra of the compounds displayed a molecular ion peak at $\mathrm{m} / \mathrm{z}$ values, which corresponds well with the theoretical value.

\section{Spectral data for selected compounds} 2,4,5-Triphenyl-1H-imidazole (Table 4, Entry a)

White solid; Yield: 95\%; m.p: $273-275^{\circ} \mathrm{C}$; IR (neat, $\left.\mathrm{cm}^{-1}\right)$ : $3216(\mathrm{~N}-\mathrm{H}), 3058(\mathrm{C}-\mathrm{H}, \mathrm{Ar}), 1628$ $(\mathrm{C}=\mathrm{N}), 1588(\mathrm{C}=\mathrm{C}) ;{ }^{1} \mathrm{H}$ NMR $\left(400 \mathrm{MHz}, \mathrm{DMSO}-\mathrm{d}_{6}\right)$ : $\delta 12.70(1 \mathrm{H}, \mathrm{s}, \mathrm{N}-\mathrm{H}), 8.10(2 \mathrm{H}, \mathrm{d}, \mathrm{Ar}-\mathrm{H}), 7.57-7.23$ $(\mathrm{m}, 13 \mathrm{H}, \mathrm{Ar}-\mathrm{H}) ;{ }^{13} \mathrm{C}$ NMR $\left(100 \mathrm{MHz}, \mathrm{DMSO}-\mathrm{d}_{6}\right): \delta$ 145.96, 137.56, 135.63, 131.54, 130.80, 129.16, 128.76, 127.53, 126.99, 125.65; Mass (m/z): Calcd for $\mathrm{C}_{21} \mathrm{H}_{16} \mathrm{~N}_{2}$ : 296.13; Found: 294.05.

\section{2-(3-nitrophenyl)-4,5-diphenyl-1H-imidazole (Table 4, Entry b)}

Yellow solid; Yield: $89 \%$; M.P: $300-302^{\circ} \mathrm{C}$; IR (neat, cm ${ }^{-1}$ ) : 3261 (N-H), 3061(C-H, Ar), 1678 $(\mathrm{C}=\mathrm{N}), 1580(\mathrm{C}=\mathrm{C}) ;{ }^{1} \mathrm{H}$ NMR $\left(400 \mathrm{MHz}, \mathrm{DMSO}-\mathrm{d}_{6}\right)$ : $\delta 12.64(1 \mathrm{H}, \mathrm{s}, \mathrm{NH}), 8.97(1 \mathrm{H}, \mathrm{s}, \mathrm{Ar}-\mathrm{H} /$ nitrophenyl), $8.57(1 \mathrm{H}, \mathrm{d}, \mathrm{Ar}-\mathrm{H} /$ nitrophenyl), $8.22(1 \mathrm{H}, \mathrm{d}, \mathrm{Ar}-\mathrm{H} /$ nitrophenyl), 7.80 (1H,t, Ar-H/nitrophenyl) 7.56-7.31 $(\mathrm{m}, 10 \mathrm{H}, \mathrm{Ar}-\mathrm{H}) ;{ }^{13} \mathrm{C}$ NMR $\left(100 \mathrm{MHz}, \mathrm{DMSO}-\mathrm{d}_{6}\right): \delta$ 148.75, 143.89, 132.33, 131.77, 130.81, 128.90 128.28, 127.83, 122.95, 119.97; Mass (m/z): Calcd for $\mathrm{C}_{21} \mathrm{H}_{15} \mathrm{~N}_{3} \mathrm{O}_{2}: 341.36$, Found 340.76 .

\section{2-isopropyl-4,5-diphenyl-1H-imidazole (Table 4, Entry i) \\ Pale yellow solid; Yield: 91\%; m.p: 231 - $233^{\circ} \mathrm{C}$; IR (neat, $\left.\mathrm{cm}^{-1}\right)$ : $3221(\mathrm{~N}-\mathrm{H}), 3031(\mathrm{C}-\mathrm{H}, \mathrm{Ar}$ ), $1686(\mathrm{C}=\mathrm{N}), 1594(\mathrm{C}=\mathrm{C}) ;{ }^{1} \mathrm{HNMR}\left(400 \mathrm{MHz}, \mathrm{DMSO}-\mathrm{d}_{6}\right): \delta$ $11.93(1 \mathrm{H}, \mathrm{s}, \mathrm{NH}), 7.65-7.39(10 \mathrm{H}, \mathrm{m}, \mathrm{Ar}-\mathrm{H}), 3.04(1 \mathrm{H}$,}


m,-CH), 1.32(6H, d, two $\left.\mathrm{CH}_{3}\right) ;{ }^{13} \mathrm{CNMR}(100 \mathrm{MHz}$, DMSO- $\quad$ 129.68, 129.00, 128.52, 127.48, 126.53, 28.23, 22.16; Mass $\left.\mathrm{d}_{6}\right): \delta$ 153.56, 136.24, 135.42, 132.72, 132.12, 130.07, $\quad(\mathrm{m} / \mathrm{z})$ : Calcd for $\mathrm{C}_{18} \mathrm{H}_{18} \mathrm{~N}_{2}: 262.35$, Found: 261.85

Table 5: Benzethonium chloride catalyzed synthesis of 1,2,4,5-tetrasubstituted imidazoles

Entry

4-(1-(2-chlorophenyl)-4,5-diphenyl-1H-imidazol2-yl)phenol (Table 5,Entry c)

White solid; Yield: 95\%; IR (neat, $\mathrm{cm}^{-1}$ ): 3430 (O-H, phenolic), 3062 (C-H aromatic), 1661 $(\mathrm{C}=\mathrm{N}), 1533\left(\mathrm{C}=\mathrm{C}\right.$, aromatic); ${ }^{1} \mathrm{H}$ NMR $(400 \mathrm{MHz}$, DMSO-d 6 ): $\delta 9.73(1 \mathrm{H}, \mathrm{s}, \mathrm{O}-\mathrm{H}), 7.94(1 \mathrm{H}, \mathrm{d}, \mathrm{Ar}-\mathrm{H})$, $7.68(2 \mathrm{H}, \mathrm{d}, \mathrm{Ar}-\mathrm{H}), 7.54-7.43(3 \mathrm{H}, \mathrm{m}, \mathrm{Ar}-\mathrm{H}), 7.41$ $7.34(2 \mathrm{H}, \mathrm{m}, \mathrm{Ar}-\mathrm{H}), 7.31-7.15(8 \mathrm{H}, \mathrm{m}, \mathrm{Ar}-\mathrm{H}), 6.6$ $(2 \mathrm{H}, \mathrm{d}, \mathrm{Ar}-\mathrm{H}) ;{ }^{13} \mathrm{C}$ NMR $\left(100 \mathrm{MHz}, \mathrm{DMSO}-\mathrm{d}_{6}\right): \delta$ 195.31, 158.30, 146.97, 137.04, 136.04, 135.01,
$134.79,132.29,131.16,130.08,129.03,128.47$, 127.31, 126.69, 121.59, 115.55; Mass (m/z): Calcd for $\mathrm{C}_{27} \mathrm{H}_{19} \mathrm{~N}_{2} \mathrm{OCl}$ : 422.12, Found: 422.16.

4-(4,5-diphenyl-1-(p-tolyl)-4,5-dihydro-1 Himidazol-2-yl)phenol (Table 5, Entry d)

Brown solid; Yield: 90\%; IR (neat, $\mathrm{cm}^{-1}$ ): 3447 (O-H, phenolic) 3062 (C-H, aromatic), 2587 (C-H, aliphatic), $1676(\mathrm{C}=\mathrm{N}), 1577(\mathrm{C}=\mathrm{C}$, aromatic); ${ }^{1} \mathrm{H}$ NMR $\left(400 \mathrm{MHz}\right.$, DMSO- $\left.\mathrm{d}_{6}\right): \delta 10.08(1 \mathrm{H}, \mathrm{s}$, 
phenolic $\mathrm{O}-\mathrm{H}), 8.45(1 \mathrm{H}, \mathrm{d}, \mathrm{Ar}-\mathrm{H}), 7.94,(3 \mathrm{H}, \mathrm{d}$, Ar-H), 7.82-7.75 (4H, m, Ar-H), 7.65-7.62 (3H ,t, $\mathrm{Ar}-\mathrm{H}), 7.24-7.07(5 \mathrm{H}, \mathrm{m}, \mathrm{Ar}-\mathrm{H}), 6.89(2 \mathrm{H}, \mathrm{d}, \mathrm{Ar}-\mathrm{H})$, $2.30\left(3 \mathrm{H}, \mathrm{s}\right.$, methyl); ${ }^{13} \mathrm{C} \mathrm{NMR}\left(100 \mathrm{MHz}, \mathrm{DMSO}-\mathrm{d}_{6}\right)$ : $\delta$ 195.1, 160.95, 159.59, 149.80, 136.05, 135.04, $132.69,130.24,128.94,128.56,128.08,126.76$, 121.26, 116.08, 115.55, 21.02; Mass (m/z): Calcd for $\mathrm{C}_{28} \mathrm{H}_{22} \mathrm{~N}_{2} \mathrm{O}: 402.49$, Found: 402.16 .

4-(1-(4-methoxyphenyl)-4,5-diphenyl-4,5-dihydro1H-imidazol-2-yl)phenol (Table 5, Entry e)

Brown solid; Yield: $89 \%$; IR (neat, $\mathrm{cm}^{-1}$ ):
3017 (C-H, aromatic), 2594 (C-H, aliphatic), 1654 $(\mathrm{C}=\mathrm{N}), 1586$ (C=C, aromatic), 1249( C-O, alkyl aryl ether); ${ }^{1} \mathrm{H}$ NMR (400 MHz, DMSO-d $\left.{ }_{6}\right): \delta 9.69(1 \mathrm{H}$, s, phenolic O-H), $7.48(2 \mathrm{H}, \mathrm{d}, \mathrm{Ar}-\mathrm{H}), 7.29,(3 \mathrm{H}, \mathrm{d}$, $\mathrm{Ar}-\mathrm{H}), 7.24-7.21(6 \mathrm{H}, \mathrm{m}, \mathrm{Ar}-\mathrm{H}), 7.16-7.14(3 \mathrm{H}, \mathrm{m}$, Ar-H ), $6.86(2 \mathrm{H}, \mathrm{d}, \mathrm{Ar}-\mathrm{H}), 6.68(2 \mathrm{H}, \mathrm{d}, \mathrm{Ar}-\mathrm{H}), 3.37$ $\left(3 \mathrm{H}, \mathrm{s}\right.$, methoxy); ${ }^{13} \mathrm{C}$ NMR (100 MHz, DMSO-d $)$ : $\delta$ $159.22,157.99,147.10,136.70,135.15,131.29$, $130.20,128.90,126.76,121.87,115.41,114.48$, 55.70; Mass (m/z): Calcd for $\mathrm{C}_{28} \mathrm{H}_{22} \mathrm{~N}_{2} \mathrm{O}_{2}: 418.17$, Found: 419.16.

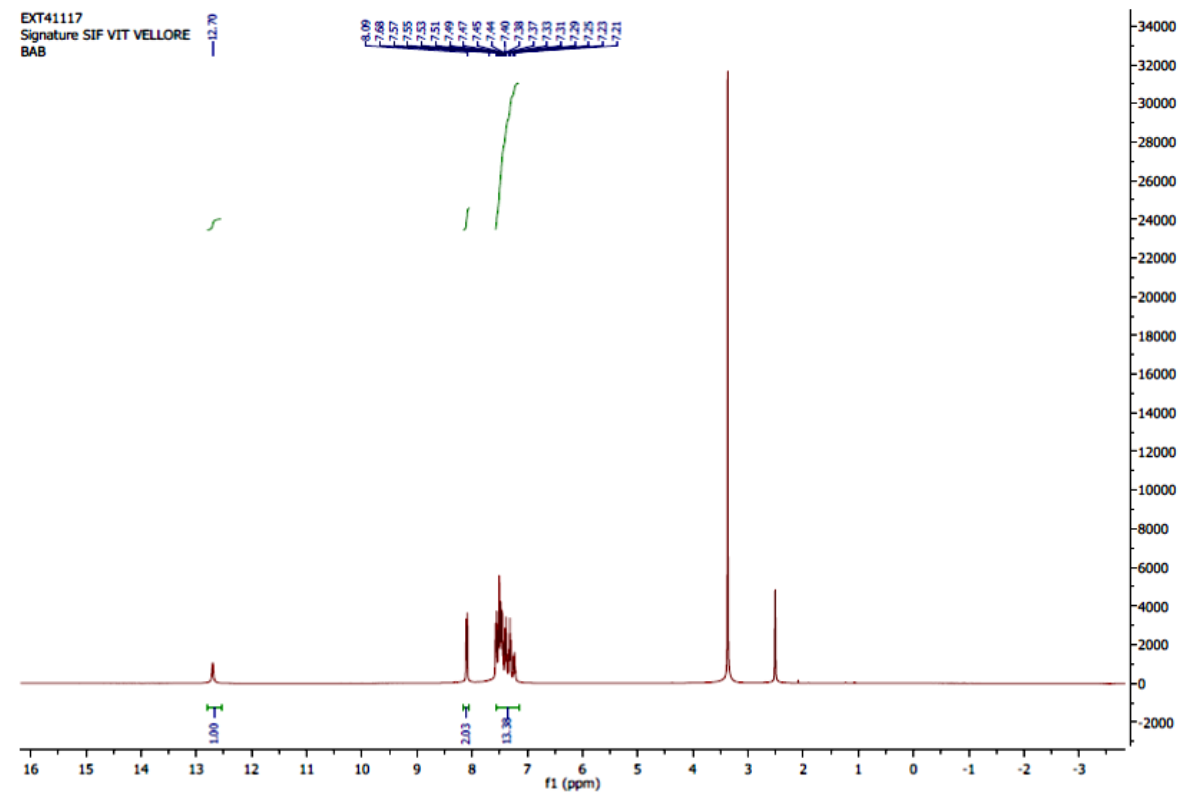

Fig. 3. ${ }^{1} \mathrm{H}$ spectra of 2,4,5-Triphenyl-1H-imidazole (Table 4, Entry a)

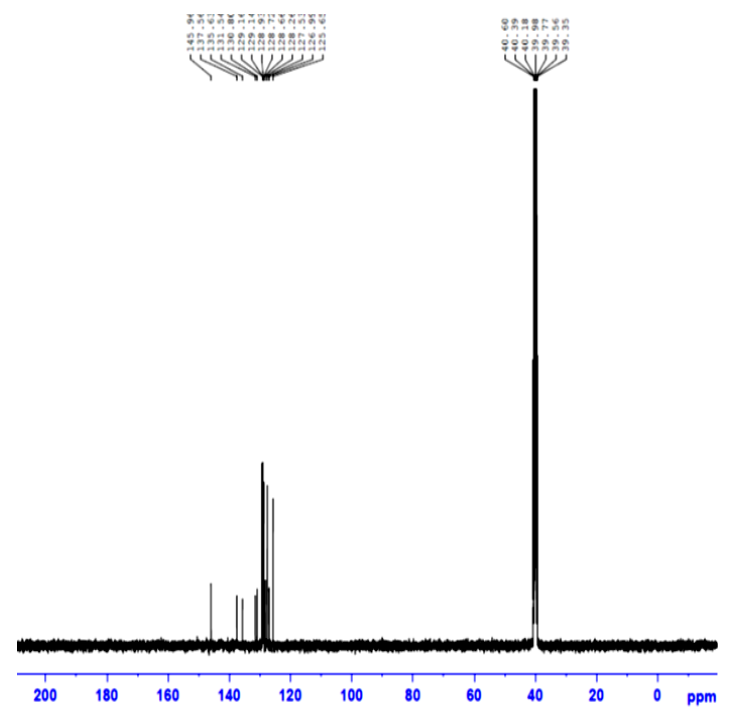

Fig. 4. ${ }^{13} \mathrm{C}$ spectra of 2,4,5-Triphenyl-1H-imidazole (Table 4, Entry a)

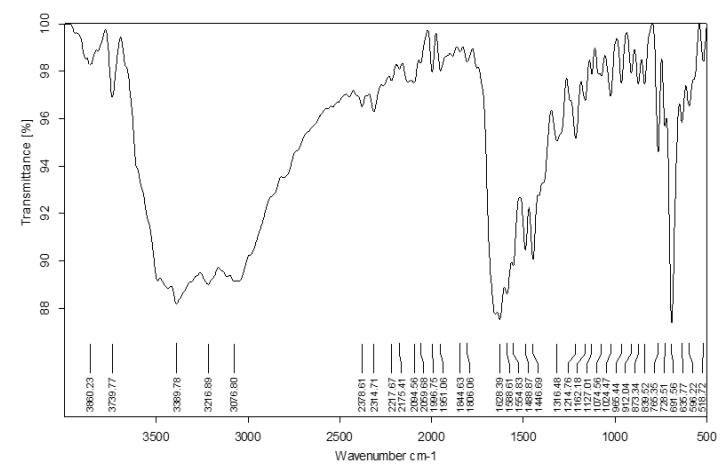

Fig. 5. IR spectra of 2,4,5-Triphenyl-1H-imidazole (Table 4, Entry a)

Benzethonium chloride can form two type of micelle depends on nature of the solvent. In a non-polar solvent, benzethonium chloride forms a reverse micelle in which the hydrophilic end of surfactant are aligned at the centre of the micelle and the hydrophobic groups spreads away from 
the centre, while in polar solvent like ethanol and water, benzethonium chloride forms regular micellar aggregation in which the hydrophobic groups of surfactant are aligned and concentrated at centre of the micelle and the hydrophilic groups spreads away from the core. ${ }^{29}$ The enhanced reaction rate is due to the fact that non-polar organic reactants are trapped easily inside the hydrophobic micelle core. The micelles formation of Benzethonium chloride in aqueous ethanol solutions increase solubility of non polar organic molecules viz benzil, aldehyde by micro-compartmentalize them, which ensures the close proximity and increased local concentrations of reactants inside the micelles, and thereby the reaction rates improves significantly (Fig. 11). Hence benzethonium chloride surfactant micellar systems act as highly efficient heterogeneous media for catalytic reactions of cyclocondensation of benzil, aldehyde and ammonium acetate.

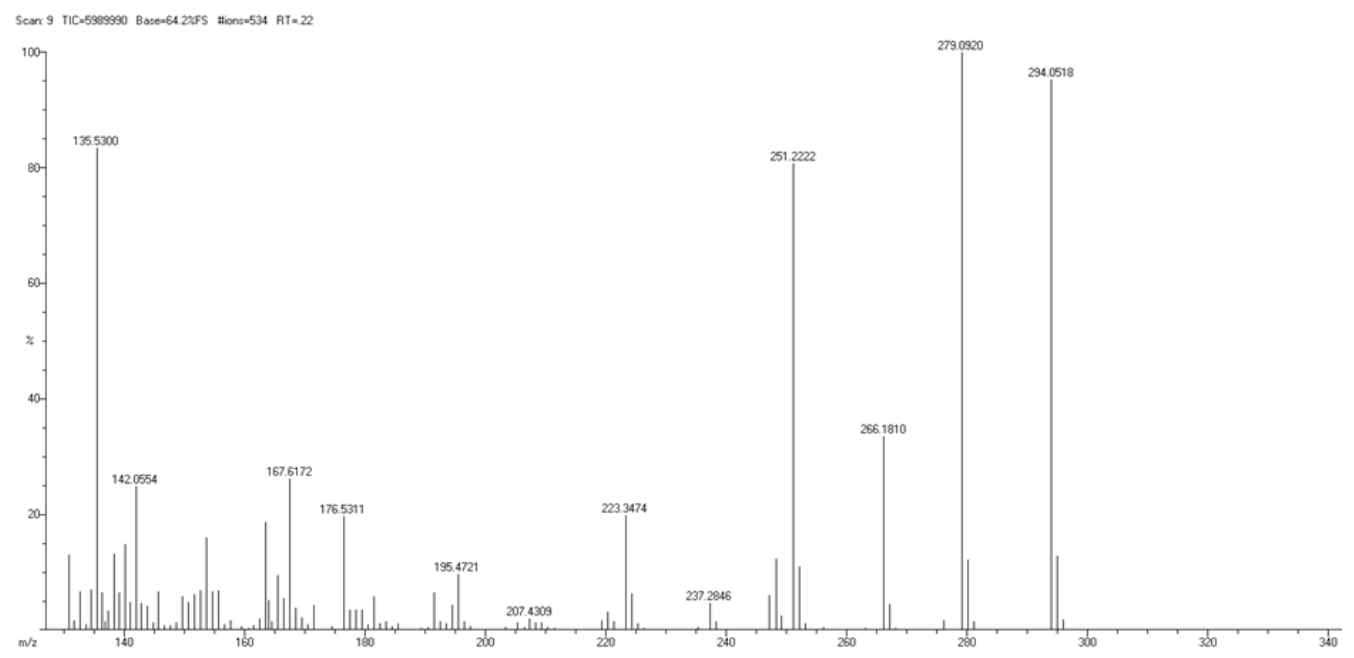

Fig. 6. Mass spectra of 2,4,5-Triphenyl-1H-imidazole (Table 4, Entry a)

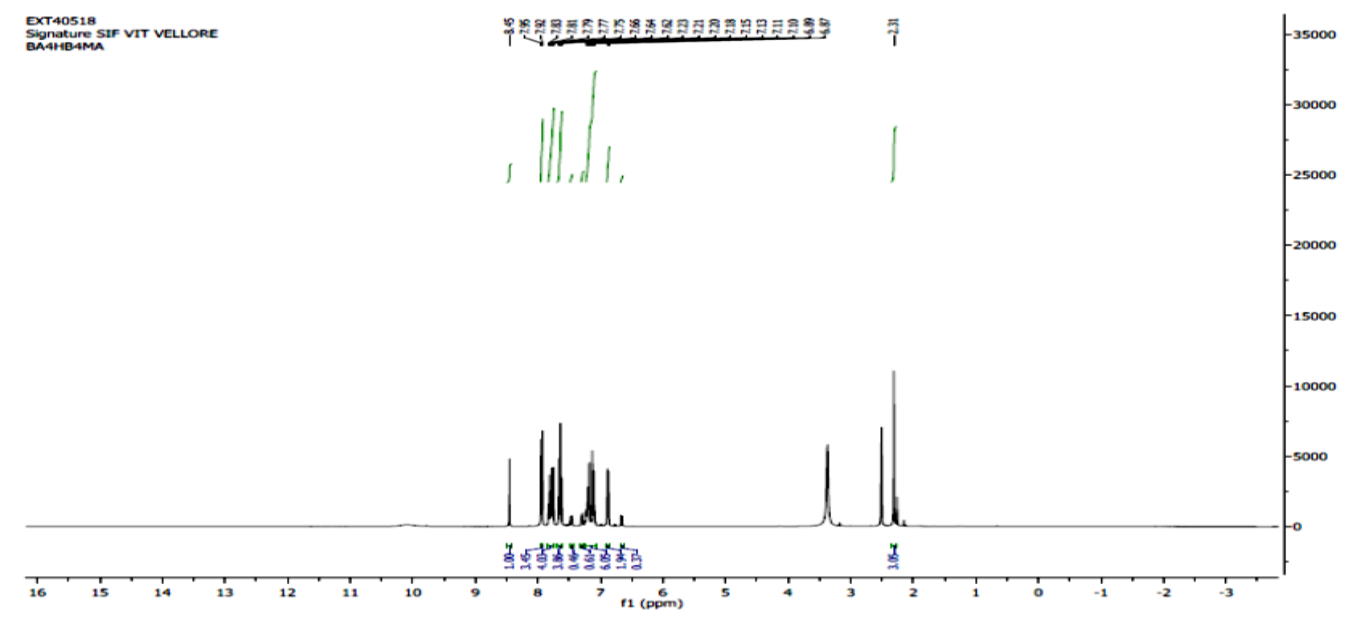

Fig. 7. ${ }^{1} \mathrm{H}$ NMR spectra of 4-(4,5-diphenyl-1-(p-tolyl)-4,5-dihydro-1H-imidazol-2-yl)phenol (Table 5, Entry d)

Moreover, the synthesis of trisubstituted imidazole involves formation of water molecules that should be removed from reaction vessel in order to shift the equilibrium dynamics towards product side. In conventional cyclocondensation reaction, water is not removed from the reaction environment which retards the reaction rate. To overcome this problem, mild to strong dehydrating agent such s sulphuric acid, phosphoric acid are usually used. But, in benzethonium chloride surfactant medium, water is effectively used for micelle formation thereby alters the equilibrium towards products, which increases the reaction speed, and this phenomenon is the key advantage of this method. 


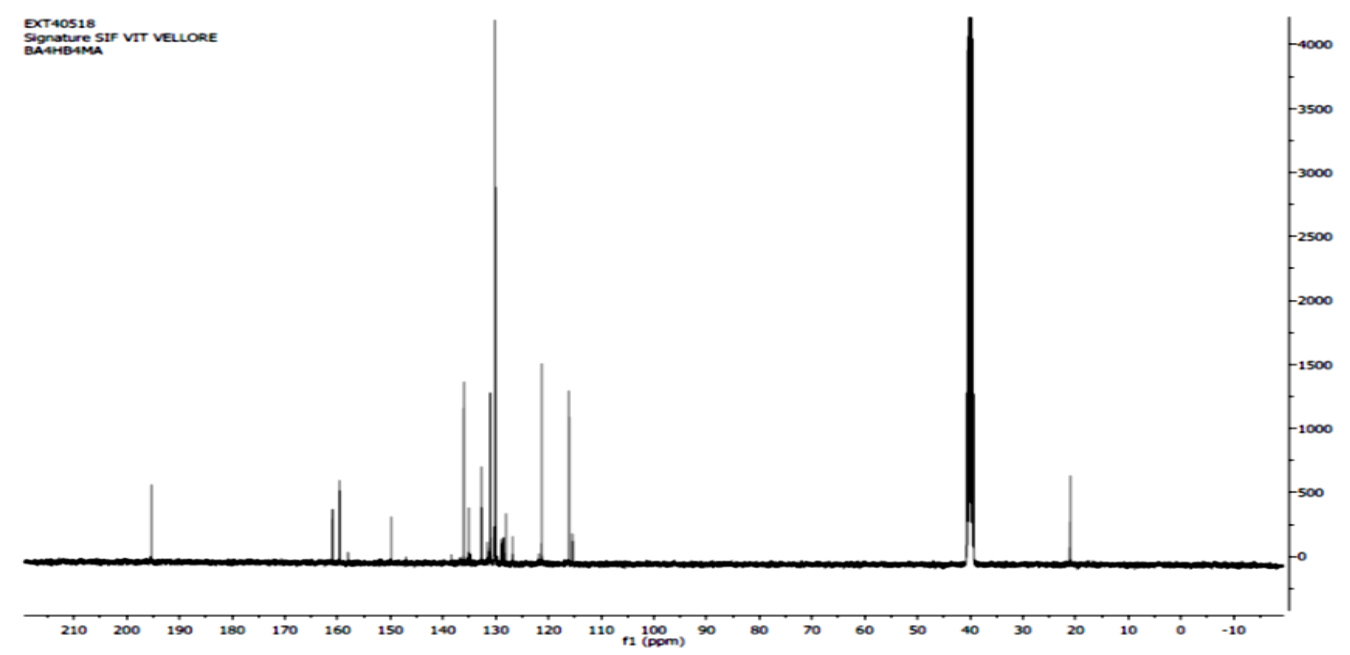

Fig. 8. ${ }^{13} \mathrm{C}$ NMR spectra of 4-(4,5-diphenyl-1-(p-tolyl)-4,5-dihydro-1H-imidazol-2-yl)phenol (Table 5, Entry d)

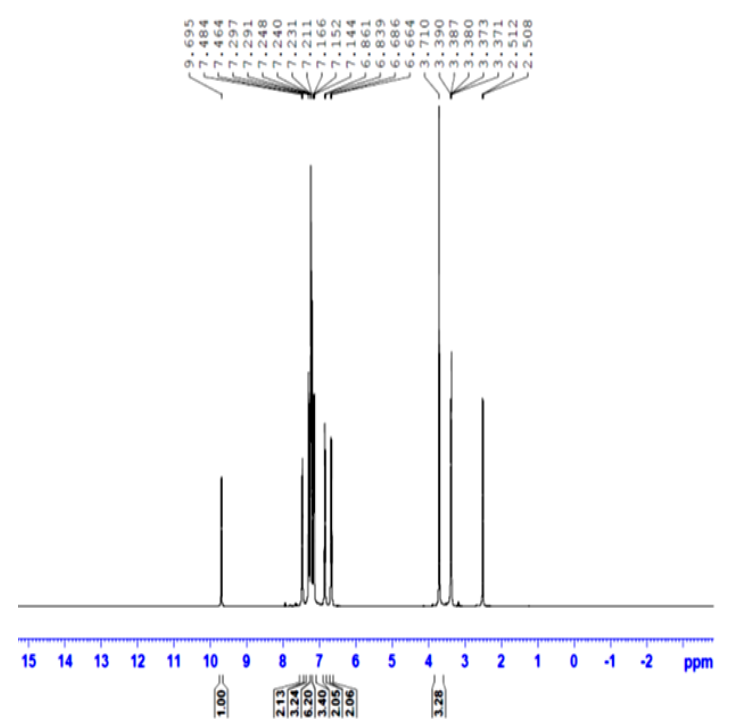

Fig. 9. ${ }^{1} \mathrm{H}-\mathrm{NMR}$ spectra of 4-(1-(4-methoxyphenyl)-4,5-diphenyl4,5-dihydro-1H-imidazol-2-yl)phenol (Table 5, Entry e)

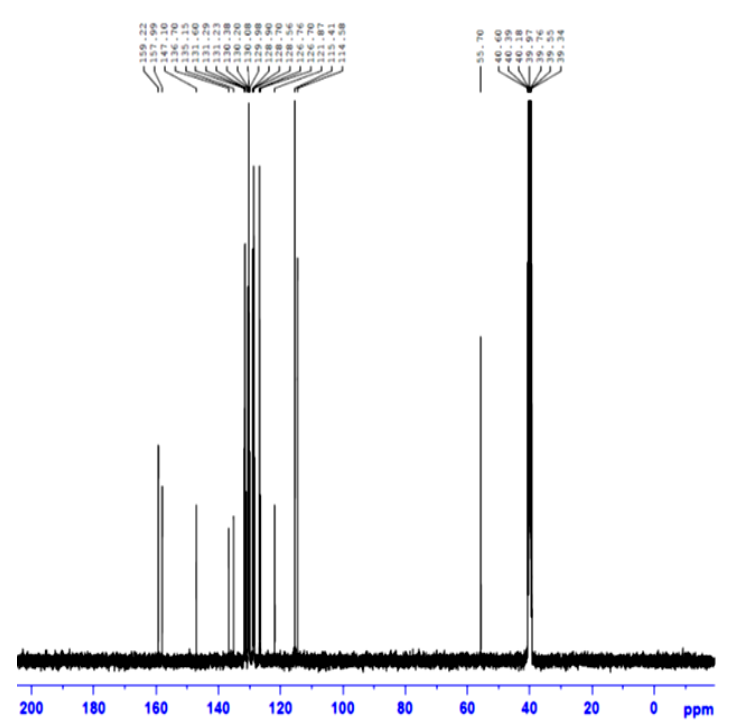

Fig. 10. ${ }^{13} \mathrm{C}-\mathrm{NMR}$ spectra of $4-(1-(4-$ methoxyphenyl)-4,5diphenyl-4,5-dihydro-1H-imidazol-2-yl)phenol (Table 5, Entry e)

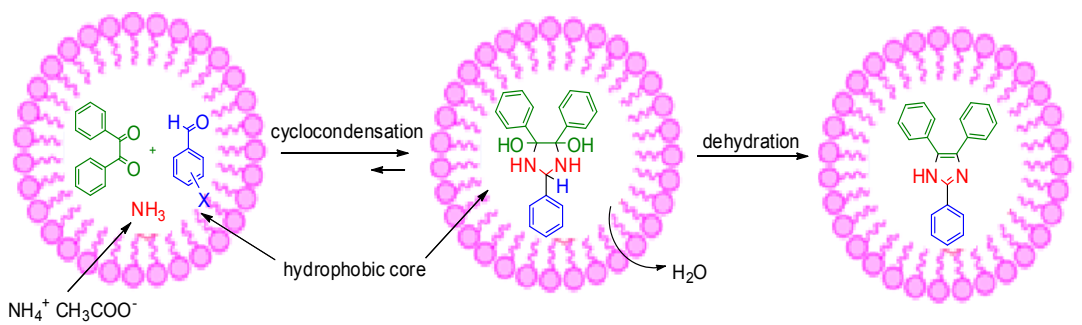

Fig. 11. Miceller promoted multicomponent synthesis of trisubstituted imidazoles

It is suggested that the catalyst benzethonium chloride increases the electrophilicity at carbon atom of carbonyl group of the aldehyde thereby it facilitates nucleophilic addition of ammonia cross polarized $\mathrm{C}=\mathrm{O}$, which leads to formation of diamine intermediate (4) by dehydration. Cyclocondenstion of intermediate (4) with benzil followed by elimination of water leads to formation of intermediate (7), which in turn undergoes ${ }^{1,5}$ proton shift to form $2,4,5$ triarylimidzole.(8) (Scheme 3). 


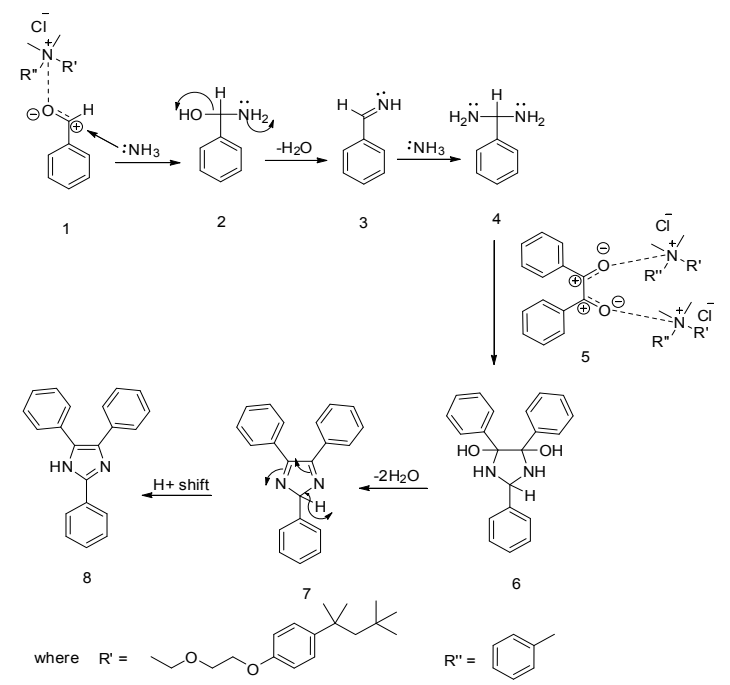

Scheme 3. Mechanism of synthesis of trisubstituted imidazoles CONCLUSION

In conclusion, we have demonstrated for the first time the effective utilization of benzethonium chloride as a sole catalyst for the one-pot three-component cyclocondensation of benzil, aromatic aldehydes and ammonium acetate in ethanol:water (1:1) solvent system. Benzethonium chloride acts both as surfactant and phase transfer catalyst. All synthesized compounds were characterized by FT-IR, ${ }^{1} \mathrm{H}$ NMR, ${ }^{13} \mathrm{C}$ NMR, and Mass spectral analysis. The developed method has several advantages compared to the conventional synthesis of tri-, tetra-aryl imidazoles that higher conversion of product was achieved in significantly lower reaction temperature and the reaction does not result in formation of undesired side product. The process also does not require the removal of water during the synthesis using vacuum distillation methods.

\section{ACKNOWLEDGEMENT}

We are thankful to Faculty of Department of Chemistry, Arignar Anna Government Arts College, Cheyyar, India-604407 and Faculty of Department of Chemistry, Madras Christian College, Chennai, India-600059.

\section{REFERENCES}

1. T.Boer, A. Amore and R.V.A. Orru, Microwaves in Organic Synthesis, Second Edition, WileyVCH, Weinheim,.., 2006, 788-819.

2. Mohammad Haji, Beilstein J. Org. Chem., 2016, 12, 1269-1301.

3. Sathe, B.S., Jaychandran, E., Jagtap, V.A., Deshmukh, S.D., Der Pharm. Chem., 2011, 3, 305-309.

4. Sondhi, S.M., Jain, S., Dinodia, M., Kumar, A., Med. Chem., 2008, 4, 146-154.

5. Ganguly, S., Vithlani, V.V., Kesharwani, A.K., Kuhu, R., Baskar, L., Mitramazumder, P., Sharon, A., Dev, A., Acta Pharm., 2011, 61, 187-201.

6. Wittine, K., Stipkovic Babic, M., Makuc, D., Plavec, J., raljevic Pavelic , S., Sedic , M., Pavelic , K., Leyssen, P., Neyts, J., Balzarini, J., Mintas, M., Bioorg. Med. Chem., 2012, 20, 3675-3685.

7. Maier, T.; Schmierer, R.; Bauer, K.; Bieringer, H.; Buerstell, H.; Sachse, B US Patent 4820335, 1989; Chem. Abstr., 1989, 111, 19494.

8. Liu J, Lee H, Huesca M, Young A, Allen C. Cancer Chemo ther Pharmacol., 2006, 58, 306.

9. Nie, Y.B., Wang, L., Ding, M.W., J. Org. Chem., 2012, 77, 696.

10. Beggs, W.H., Andrews, F.A., Sarosi, G.A., Life
Sci., 1981, 28, 111-118.

11. Lindberg, P., Nordberg, P., Alminger, T., Brandstorm, A., Wallmark, B., J. Med. Chem. 1986, 29, 1327-1329.

12. S.L. Abrahams, R.J. Hazen, A.G. Batson, A.P. Phillips, J. Pharmacol. Exp. Ther., 1989, 249, 359-365.

13. Grange, R.L., Ziogas, J., North, A.J., Angus, J.A., Schiesser, C.H., Bioorg. Med. Chem. Lett., 2008, 18, 1241-1244.

14. T. Welton, Chem. Rev., 1999, 99, 2071.

15. Satoru, Japn Kokkai Tokyo Koho JP 01, 117, 867, 10 May, 1989, Chem. Abstr., 1989, 111, 214482.

16. Ashok V. Borhade, Dipak R. Tope, Sandip G. Gite, Arab J Chem., 2017, 10, S559-S567.

17. Hemant V.Chavan, Dattatraya K.Narale, Comptes Rendus Chimie., 2013, 17, 980984.

18. Ghodsi Mohammadi Ziarani, Alireza Badiei, Negar Lashgari, Zahra Farahani, J. Saudi Chem. Soc., 2016, 20, 419-427.

19. Muhammad Ya, Marek Bajda, Sohail Shahzad, Nisar Ullah, Mazhar Amjad Gilani, Muhammad Ashraf, Abdul Rauf, Ayesha Shaukat, Bioorg. Chem., 2015, 58, 65-71. 
20. Ali Akbari, Tetrahedron Lett., 2016, 57, 431-434.

21. Najmoddin Aziizi, Zohreh Manochehri, Adnan Nahayi, Sohila Torkashvand, J. Mol. Liq., 2014, 196, 153-158,.

22. Laxmikant D. Chavan, Sunil G. Shankarwar, Chin. J. Catal., 2015, 36, 1054-1059,

23. Chung-Yu Chen, Wan-Ping Hu, Pi-Cheng Yan, Gopal Chandru Senadi, and Jeh-Jeng Wang, Org. Lett., 2013, 15, 6116-6119,

24. Mahmoud. Abd El Aleem. Ali. Ali El-Remaily, Ahmed M. Abu-Dief, Tetrahedron., 2015, 71, 2579-2584.

25. Marina Gorsd, Gabriel Sathicq, G. Romanelli, L. Pizzio, M. Blanco, J. Mol. Catal. A:Chemical., 2016, 420, 294-302.

26. Mohammad Ali Zolfigol, Ardeshir Khazaei, Ahmad Reza Moosavi-Zare, Abdolkarim Zare, Zhila Asgari, Vahid Khakyzadeh, Alireza Hasaninejad, J.Indus Engg Chem., 2013, 19, 721-726.

27. Javad Safari, Simin Naseh, Zohre Zarnegar, Zahra Akbari, J. Taibah Univ. Sci., 2014, 8, 323-330.

28. Juan S. Milano-Brusco, Henriette Nowothnick, Michael Schwarze, and Reinhard Schomacker, Ind. Eng. Chem. Res., 2010, 49, 1098-1104,

29. B.Samiey, C.H. Cheng, J.Wu, J.Chem., 2014, 14, 908476.

30. Mohammad Heidari, Mohsen Rezaei, Rashid Badri, Heterocycl Commun., 2014, 21, 73-76.

31. [31] Chary, M. V.; Keerthysri, N. C.; Vupallapati,
S. V. N.; Lingaiah, N.; Kantevar, S. Catal. Commun., 2008, 9, 2013-2017.

32. Frantisek Kopecký, Die Pharmazie., 1996, 51, 135-44.

33. Bojan Šarac, Marija Bešter-Rogac, J. Coll Interf Sci., 2009, 338, 216-221,

34. Attwood. D., Terreros. A., Lopez-Cabarcos. E., Galera-Gomez. P. A., Journal of Colloid and Interface Science., 2000, 225, 25-31.

35. Zana. R., Langmuir., 1996, 12, 1208-1211,

36. The Merck index; An Encyclopedia of Chemicals, Drugs, and Biologicals, 11 th edition, 1989, 1084.

37. Jin Zhang, Decheng Ren, Yangmin Ma, Weitao Wang, Hao Wu, Tetrahedron., 2014, 70, 5274-5282.

38. Christian Capello, Ulrich Fischer, Konrad Hungerbuhler, Green Chem., 2007, 9, 927-934.

39. R. Joel karunakaran, R. Sathiyapriya, Synthetic communication., 2006, 36,1915-1917.

40. R. Joel karunakaran ,R. Sathiyapriya, Asian J. Chem., 2006, 18, 1321-1325.

41. R. Joel karunakaran ,R. Sathiyapriya, E-J. Chem., 2006, 3, 65-67.

42. R. Joel karunakaran,R. Sathiyapriya, J. Chem Research., 2006, 9, 575-576.

43. D.Parthiban, R.Joel Karunakaran and C.J.Magesh, Inter. Res. J. Pure. App. Chem., 2018, 16, 1-10. 